\title{
Determinants of CEO Compensation before and after the Financial Crisis
}

\author{
Ralph Sonenshine, Nathan Larson, Michael Cauvel \\ Economics Department, American University, Washington DC, USA \\ Email:Sonenshi@american.edu,Nathan.Larson@american.edu,mc1465a@student.american.edu
}

How to cite this paper: Sonenshine, R., Larson, N. and Cauvel, M. (2016) Determinants of CEO Compensation before and after the Financial Crisis. Modern Economy, 7, 1455-1477.

http://dx.doi.org/10.4236/me.2016.712133

Received: July 16, 2016

Accepted: November 13, 2016

Published: November 16, 2016

Copyright $\odot 2016$ by authors and Scientific Research Publishing Inc. This work is licensed under the Creative Commons Attribution International License (CC BY 4.0).

http://creativecommons.org/licenses/by/4.0/

\begin{abstract}
This paper revisits the determinants of CEO compensation using recent data (covering 125 firms from 2003 to 2012). We focus in particular on how CEO pay changed after the 2008 financial crisis. Post-crisis, the composition of pay shifted away from cash toward equity. Furthermore, post-crisis pay is tied more closely to performance and less closely to factors (like firm size) that are more tenuously connected to shareholder value. We also investigate the impact of mergers and divestitures on CEO pay, overall and before and after the crisis. Finally, we consider the role that board composition plays in CEO compensation and find that CEOs take larger post-crisis pay cuts when they have more employees on their boards.
\end{abstract}

\section{Keywords}

Mergers and Divestitures, CEO Compensation, Board Composition, Stock Market Performance, Principal Agent, Managerial Power

\section{Introduction}

Over the past twenty-five years CEO compensation of the top 350 firms in the US has grown $875 \%$, or more than twice the $354 \%$ growth in wages of the average worker. ${ }^{1}$ This rapid increase appears even more dramatic when option and stock awards to CEOs are considered, and it outstrips the growth in pay of other highly paid workers. This trend has sparked renewed interest in understanding the factors that determine CEO compensation and whether changes in these factors impact the recent surge in pay. Much of the debate centers on whether CEO pay is earned (for good performance and productivity) or captured (by extracting rents from a weak board). The first view predicts that pay should be linked to observable measures of firm performance, such as

${ }^{1}$ See http://www.epi.org/publication/ceo-pay-2012-extraordinarily-high/. Frydman and Saks (2010), however, find that in the period from 1936-1980, CEO compensation was grew slower than firm size [2]. 
stock price and earnings, in order to provide CEOs with incentives; the latter suggests that pay depends on the availability of rents and the bargaining power of the CEO vis-à-vis the board and shareholders.

At the same time, it is a well-established, empirical fact that size matters: all else equal, CEOs of larger firms are paid more. Both schools of thought on pay can reconcile this fact, but with different explanations. If one believes in pay for performance, then one argues that larger firms attract more talented chief executive officers. Pay for performance amplifies a CEO's productivity by scaling up the resources under his control, or demands stronger incentives to keep leadership on the straight and narrow. Under the rent-seeking view, larger firms are harder for the board to monitor and offer more opportunities for the CEO to skim. Therefore, as Core et al. (1999) note CEO compensation may be expected to be a function of firm size, complexity, growth opportunities, and board structure, as well as firm performance and stock market volatility [1].

One highly visible way for a CEO to influence his firm's size (and so perhaps his pay) is with mergers and divestitures. Ideally, any link between an acquisition or divestiture and CEO pay should be related to whether the deal improves shareholder value. However, because mergers grow a firm and divestitures shrink it, the strong link between size and pay may play a role as well. Furthermore, the fact that mergers and divestitures are large, concrete changes for which the CEO can credibly and publicly take responsibility may prompt CEOs to pursue potentially questionable acquisitions rather than more incremental changes in a firm's size.

This paper explores these determinants of CEO pay with a particular focus on changes before and after the 2008 financial crisis. The financial crisis was a major shock to the US economy that forced many firms to seriously reassess their status quo operations. It would not be surprising if, as part of this reassessment, attitudes about determining executive compensation changed as well. As shown in Figure 1 and Table 3, CEO compensation declined substantially at the onset of the financial crisis but then recovered with the economy. However, the composition of CEO compensation appears

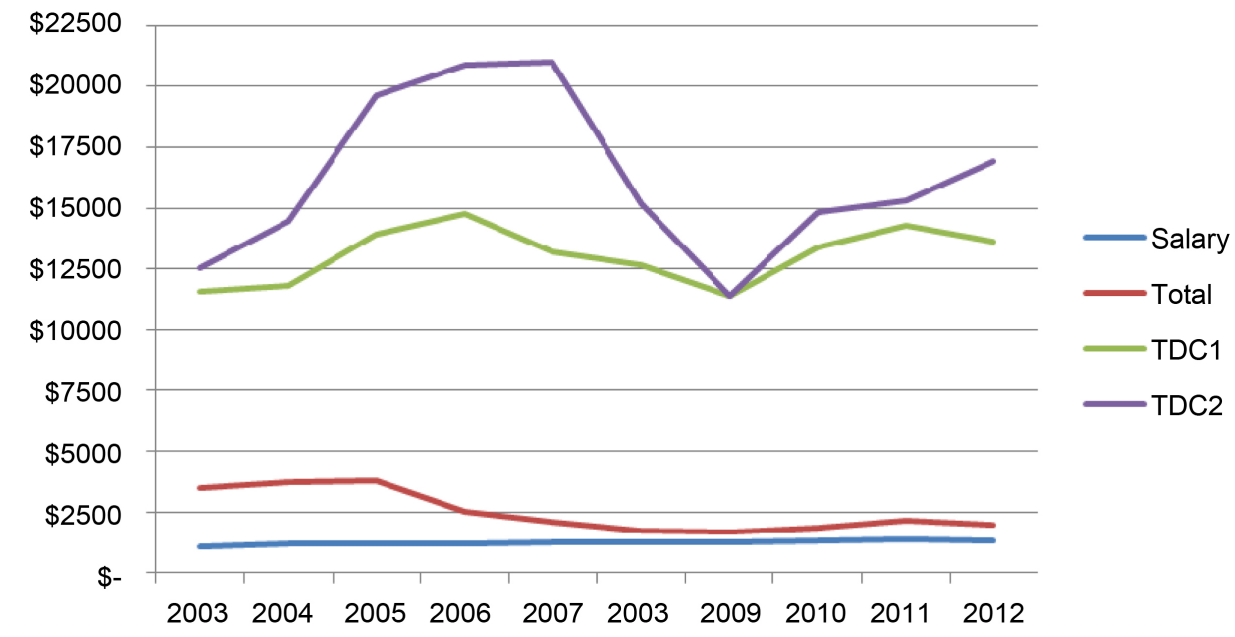

Figure 1. Annual executive compensation by type (in $\$ 1000$ ). 
to have changed.

Indeed, we find that CEO compensation did change after the crisis, and the main changes involve pay that appears more closely tied to performance. First, after controlling for other effects, the composition of pay changed away from cash toward equity and options. Second, factors associated with shareholder value (such as earnings per share and stock performance) became more strongly linked to pay, while factors less obviously related to shareholder value (such as firm size) diminished in importance.

While CEOs appear to be paid for doing deals (either mergers or divestitures), this effect largely disappears after including a post-crisis dummy. Transactions drop substantially after 2008, suggesting that the apparent "transaction bonus" may largely reflect higher pay during frothier economic times.

The literature is mixed on the empirical effects of board composition on pay. Our results do not resolve the question, but they add a new wrinkle. The usual comparison is between independent and affiliated board members. While the most obvious prediction is that affiliated directors will be associated with higher pay (because they have ties to the firm and so may exert less discipline), there are competing theories and the evidence is unsettled. We find that all outside board members, independent or affiliated, are associated with higher $\mathrm{CEO}$ cash compensation compared to board members who are employees. Furthermore, this difference is concentrated entirely after the financial crisis; in effect this means that CEOs with more employee directors took larger postcrisis pay cuts than those with more outside directors.

The layout of the paper is as follows. Section 2 reviews the relevant literature. Section 3 discusses our data and empirical strategy. Section 4 presents our regression results, and Section 5 provides some concluding remarks.

\section{Literature Review}

\subsection{Schools of Thought}

There are two prevailing schools of thought on what determines CEO pay. The principal-agent view (as articulated by Core et al. 2003, among many others) suggests that boards design CEO compensation contracts so as to provide incentives for CEOs to work hard and maximize shareholder value [3]. Alternatively, the managerial power view (Bebchuk and Fried, 2003) asserts that CEOs exert influence over their boards that effectively allows them to participate in setting their own pay [4]. The two approaches suggest different explanations for large pay packages; under the principal-agent approach, high average levels of pay may be necessary to compensate the CEO for the risk he bears by having his compensation tied to firm performance (via stock and options), whereas under the managerial power approach high pay might indicate weak corporate governance-specifically, a high degree of leverage for the CEO over the board and compensation committee. Crystal (1991) argues that boards of directors over-compensate senior executives because outside directors are hired by the CEO and can be removed by the CEO [5]. Likewise, Lambert et al. (1993) and Boyd (1994) find a positive relation between $\mathrm{CEO}$ compensation and the percentage of the board composed of 
outside directors [6] [7]. However, Finkelstein and Hambrick (1989) conclude that compensation is unrelated to the percentage of outside directors on the board [8]. Conyon (2006) provides a survey of the evidence supporting these alternative perspectives [9].

Empirical evidence for the managerial power argument has focused on linking CEO pay to measures of board capture or weak corporate governance. Chhaochharia and Grinstein (2009) show that when new standards for board independence were introduced in the wake of corporate scandals in the early 2000s, CEO pay declined disproportionately at firms most affected by the new rules [10]. In a sample of IPO firms, Conyon and $\mathrm{He}$ (2004) find that CEOs with large stakeholders on the board (who are presumably stronger monitors) get pay packages tied more closely to firm performance (less cash and more equity) [11]. However, the evidence is not uniform; for example, Boyle and Roberts (2013) find that CEOs of New Zealand firms who sit on the board compensation committee are paid less than those who do not [12]. Sur et al. (2015) find cash compensation is mostly driven by firm specific factors, while equity driven compensation is largely determined by time-varying factors with firm and industry effects playing a minor role [13]. Frydman and Saks (2010) add that there has been a fundamental transformation in CEO compensation with stock options becoming a greater portion of total compensation.

Murphy (2002) rebuffs the managerial power hypothesis in part by finding that there is an insignificant difference in total compensation between CEOs hired from the inside versus the outside [14]. Murphy (2002) concludes that this finding is inconsistent with the managerial power view that insider CEOs use their relationships with the boards to extract rents. Instead, he attributes his findings to differences in preferences for riskier stock options between outsider and insider CEOs.

Meanwhile, there is a substantial body of empirical evidence that CEO pay is increasing in firm size (Kostiuk 1989, Murphy 1985) [15] [16]; typical estimates put the elasticity of pay with respect to size at 0.25 (so a $10 \%$ increase in size is associated with a $2.5 \%$ increase in pay). Under the principal-agent perspective, this relationship can be seen as reflecting the need to give the CEOs of larger firms, incentives commensurate with the larger economic impact of their actions (Gayle and Miller 2009) [17]. In contrast, the more cynical view of the managerial power approach would be that larger firms present CEOs with more opportunities to carve out rents (Bebchuk and Fried 2003).

This empirical relationship adds nuance to a concern with older roots: namely that CEOs are interested in empire-building for its own sake. Writers, such as Marris (1964) and Aoki (1984) argued that, unencumbered by external constraints, executives are more interested in increasing firm size than maximizing shareholder value [18] [19]. Tosi et al. (2000) attributes this in part to the idea that CEOs can exert more complete control over firm size than performance [20].

In light of this empirical evidence, a growing theoretical literature has attempted to elaborate on the reasons that firm size and CEO pay might be linked. Rosen (1992) 
suggests that the marginal productivity of a CEO may scale up with firm size because his decisions affect how a larger pool of employees and resources are deployed [21]. When this is so, competitive labor markets will tend to match more talented CEOs with larger firms where they are paid according to their productivity, establishing a positive association between size, CEO ability, and pay. Baker and Hall (2004) extend this theory and take it to the data, finding support for the conjecture that CEO productivity rises with firm size [22]. Building on these results, Gabaix and Landier (2008) develop a competitive equilibrium assignment model of the market for CEO talent and show that calibrated predictions of pay can help to explain not only the size-pay correlation but also time series and cross-country patterns in pay [23]. Tosi et al. (2000) concur that reasons for the size-pay correlation include greater complexity, more stratification, and greater human capital at larger firms.

\subsection{CEO Compensation and Mergers and Divestitures}

Under the principal agent view, $\mathrm{CEO}$ compensation is linked to firm size, giving rise to the question whether CEO motives for consummating mergers and divestitures. Mergers and divestitures are highly visible actions that a CEO can take to grow or shrink his firm, respectively; if he expects these actions to be rewarded or punished in future compensation, there may be a temptation to make decisions that are not aligned with maximizing firm value. On the question of mergers, it has long been suspected that CEOs may be prone to empire-building at the expense of shareholder value. This view is bolstered by considerable empirical evidence that stock markets treat merger announcements as negative news for the acquiring firm and that acquirers tend to overpay for their acquisitions (Moeller et al. 2004) [24].

A number of studies have found that CEOs tend to be rewarded for mergers with higher pay (Hartford and Li 2007, Grinstein and Hribar 2004, Yim 2013) [25]-[27]. Harford and Li (2007) find that growth via internal capital investments is not similarly rewarded and suggest that, for some reason, mergers give CEOs particular leverage in bargaining with boards for better pay. Yim (2013) shows that the pay increase in the year after an acquisition is retained in subsequent years (thus strengthening the incentives of all CEOs to complete mergers, but particularly younger ones who will enjoy these gains over a longer career horizon). If CEOs pursued only mergers that were in their shareholders' interest, then rewarding them for mergers might be appropriate. Harford and Li (2007) address this by examining the relationship between CEO pay and his firm's post-merger performance. They find that the overall pay gain from mergers conceals an asymmetry: CEOs are rewarded for mergers that turn out well but are not punished for mergers that turn out poorly. One conceivable explanation is that captured, or partially captured boards, tend to insulate CEOs from the downside consequences of their mistakes. In fact, there is a body of evidence indicating that unwarranted generosity after mergers is exacerbated by weak corporate governance (Harford and Li 2007, Grinstein and Hribar 2004). Grinstein and Hribar (2004) find that weaker boards tend to grant larger bonuses for mergers. Harford and $\mathrm{Li}$ (2007) show that CEOs 
are punished for poor post-merger performance when the board is strong. Furthermore, CEOs with weaker boards tend to make deals that are larger and less profitable (as judged by market reaction) (Harford and Li 2007), suggesting that they may not anticipate consequences for failure.

In contrast with the healthy literature on mergers, there is relatively little evidence on how divestitures and other decisions to shrink the firm affect CEO pay. In principle, divestitures should be rewarded or punished, just as with mergers, on the basis of their effect on shareholder value. Bebchuk and Grinstein (2005) find the asymmetric result that increases in firm size lead to higher pay, but decreases in size (measured either by sales or market capitalization) do not cause pay to fall [28]. In one of the few studies to focus explicitly on divestitures, Haynes et al. (2007) examine panel data from British firms [29]. They find that in general, CEOs are punished for divestitures via the robust link between firm size and pay, suggesting that CEOs will have little incentive to downsize even when it is the right thing to do. However, firms with strong boards are an exception to this rule: they tend to reward CEOs for divestitures.

This paper then examines the influence of mergers and divestitures on CEO pay. As part of the analysis, we also assess the influence of board composition and the way these factors have been changing over time, particularly pre and post financial crisis.

\subsection{CEO Compensation and the Financial Crisis}

Finally, the level and mix of CEO compensation may have changed since the financial crisis of 2008. Gabaix et al. (2014) examine the size-CEO compensation relationship before and after the financial crisis and find the effect to be very similar between the two periods with compensation going up proportionally pre-crisis and going down at a similar rate post crisis. Vemala et al. (2014) also found that firm size along with firm performance and board composition had similar effects on CEO compensation, pre and post financial crisis [30]. They, however, also found that while total compensation increased during and after the 2008 financial crisis, cash compensation decreased. Faulkender et al. (2010) had similar findings that CEO compensation increased while stock market prices fell [31]. These findings conflict, in some respects, with the agency view of CEO compensation since stock prices and earnings declined significantly in 2009. This paper adds to the literature by assessing how the financial crisis altered the determinants of CEO compensation.

\section{Hypotheses, Data and Empirical Methodology}

\subsection{Hypotheses}

This paper tests three hypotheses:

Hypothesis 1: CEO compensation is influenced by the financial crisis. We hypothesize that the financial crisis had a disciplining effect altering CEO compensation contracts toward variable compensation (tied to stock market performance and earnings per share) as measured by TDC 1 or TDC 2 and away from cash compensation as measured by salary and/or total compensation. In addition, we expect pay for perfor- 
mance to have a greater effect on CEO compensation post versus pre-financial crisis. In other words we hypothesize that financial performance variables, such earnings per share of stock market performance, interacted with the financial crisis effect will have a positive influence on CEO compensation.

Hypothesis 2: CEO compensation is positively influenced by merger announcements and/or relative merger value, as measured by merger value percentage (transaction value/firm market capitalization), since mergers add to firm size. We, however, do not expect CEO compensation to be significantly impacted by divestitures because divestitures reduce firm size but also may trim poor performing businesses. As a corollary, we expect this effect to be altered in the post financial crisis period with mergers not having a significant impact on CEO compensation post financial crisis

Hypothesis 3: Following recent evidence on the disciplining effect of more independent boards, we expect CEO compensation to be decreasing in the fraction of independent board members (relative to affiliate and employee members). On the theory that independent boards will respond more forcefully to the shock of the financial crisis, we conjecture that this effect will grow stronger post-2008.

\subsection{Data}

The paper analyzes CEO compensation for a set of 123 US companies $(24.6 \%$ of the S\&P 500) over a ten-year time period between Jan 1, 2003 and December 31, 2012, spanning equally before and after the financial crisis. In order to assess the effect of large mergers and divestitures, the sample was restricted to companies that engaged in a merger or a divestiture with a transaction value greater than $\$ 1$ billion. Data on merger and divestiture values and announcement dates were found using the SDC Thomson database. The data set includes 97 companies that engaged in a merger or divestiture and 26 other companies ${ }^{2}$ that did not engage in a large merger ( $>\$ 1$ million) during the ten-year time span. Each of the 26 companies was selected because it is a leading competitor for one of the 97 merging companies.

CEO compensation was measured in four ways: salary, total current compensation (salary plus bonus), TDC 1 (Total Direct Compensation 1), and TDC 2 (Total Direct Compensation 2). Compensation data was taken from the Execucomp section of the Compustat database, a Wharton Research Division Service (WRDS) database that provides company specific data to include various measures of CEO compensation, Company sales, profit, and company director information. CEO compensation can measured by salary, salary plus bonus, or salary plus bonus plus stock compensation (TDC 1 or TDC 2). TDC 1 estimates the value of total compensation realized by the executive in a given year, measured by salary, bonus, the value of restricted stock granted, the total value of stock options exercised, and the value of long-term incentive payouts. Thus TDC 1 comprises the value of total compensation awarded (but not necessarily realized) to the executive that year. TDC 2 estimates the value of total compensation using

${ }^{2}$ For many of the 97 companies, we could not find a key publicly-held competitor that did not engage in a large merger during the ten-year time span. 
the same method except it replaces the value of restricted stock granted with the net value of stock options exercised. As Kaplan and Rauh (2010) explain: “...TDC 2 will be closer to an executive's true adjusted gross income while TDC 1 will more closely approximate the compensation a company's board expected to pay the executive" [32].

Firm size was measured using the firm's sales. Lagged firm sales ${ }^{3}$ were used because, when considering pay for performance, CEO compensation is awarded after the firm's prior year financial performance is completed.

We also investigated the effect of profitability, as measured by earnings per share (EPS) from operations (lagged), on CEO pay to explore whether the link between pay and performance. We also used the firm's annual stock market performance (lagged) as an independent variable to measure pay for performance. ${ }^{4}$ Profitability measures along with firm sales were taken from the Compustat database, while stock market and S\&P data were gathered using the Center for Research in Security Prices (CRSP) database. We expect EPS and annual stock market returns to have a positive effect on incentive compensation.

In addition, we used dummy variables to control for whether the CEO was a new hire (1) and whether he was hired from outside (1) or inside the firm. We expect that incentive compensation will be lower if the CEO is a new hire, as incentives may be built in over time. Also, we expect that CEOs hired from the outside may receive higher salary or incentive compensation than inside hires, based on the theory that the firm faces more competition for outside hires (both from the CEOs' current employers and from other firms trying to hire them). Finally, we interacted new hire and outside under the theory that new hires that were inside the firm may be in a better position to extract rents from the board than outside new hires.

Finally, we examined board composition using the Risk Metrics database. Each board member is categorized in this database as being an employee, linked (affiliated ${ }^{5}$ ), or independent. It has been assumed that the higher the percentage of affiliated board members the higher the CEO compensation, though statistical studies have not completely borne this out (see Hallock 1997; Core et al. 1999, and Fich and White 2003) [33] [34]. We also hypothesize that independent board members are chosen by the CEO suggesting they would award the CEO higher compensation than an employee board member.

\subsection{Summary Statistics}

Table 1 shows company sales, market capitalization, and compensation by industry. From the table we see that the sample is fairly well dispersed between industries. The

\footnotetext{
${ }^{3} \mathrm{We}$ also estimated the effect using firm market capitalization and found similar (unreported) results. We chose firm sales because the R-squared regression results were slightly higher when using firm sales versus market capitalization.

${ }^{4} \mathrm{We}$ tried both total and net stock market performance (subtracting out the benchmark index annual performance), but did not find differences in significance between the variables.

"Affiliated" refers to a board of director's member, who may be either a retired employee or one who does business with the organization on which he/she serves as a member of the board (see Economic Research web site http://www.erieri.com/glossary/term/affiliated\%20director/45).
} 
Table 1. CEO compensation by industry.

\begin{tabular}{cccccccc}
\hline Industry & Frequency & $\begin{array}{c}\text { Size } \\
\text { (Market } \\
\text { Cap in } \\
\text { Billions) }\end{array}$ & $\begin{array}{c}\text { Size (sales } \\
\text { in Billions) }\end{array}$ & $\begin{array}{c}\text { Salary } \\
\text { (in 000s) }\end{array}$ & $\begin{array}{c}\text { Total } \\
\text { Current } \\
\text { Compensation } \\
\text { (000s) }\end{array}$ & $\begin{array}{c}\text { TDC 1 } \\
\text { (in 000s) }\end{array}$ & $\begin{array}{c}\text { TDC 2 } \\
\text { (in 000s) }\end{array}$ \\
\hline Consumer & 20 & $\$ 44,629$ & $\$ 27,417$ & $\$ 1742$ & $\$ 4176$ & $\$ 14,599$ & $\$ 16,988$ \\
Technology & 19 & $\$ 59,263$ & $\$ 33,698$ & $\$ 982$ & $\$ 1786$ & $\$ 14,439$ & $\$ 19,463$ \\
Industrial & 20 & $\$ 36,796$ & $\$ 33,764$ & $\$ 1278$ & $\$ 2275$ & $\$ 10,926$ & $\$ 11,361$ \\
Financial & 14 & $\$ 76,588$ & $\$ 57,089$ & $\$ 1144$ & $\$ 4017$ & $\$ 17,262$ & $\$ 21,201$ \\
Healthcare & 21 & $\$ 46,417$ & $\$ 26,607$ & $\$ 1195$ & $\$ 1881$ & $\$ 11,200$ & $\$ 13,585$ \\
Oil and gas & 15 & $\$ 58,857$ & $\$ 66,217$ & $\$ 1341$ & $\$ 2487$ & $\$ 13,944$ & $\$ 21,825$ \\
Retail & 6 & $\$ 33,901$ & $\$ 67,533$ & $\$ 1263$ & $\$ 2323$ & $\$ 20,516$ & $\$ 26,128$ \\
Transport & 3 & $\$ 13,858$ & $\$ 22,485$ & $\$ 749$ & $\$ 1221$ & $\$ 6569$ & $\$ 9416$ \\
Utility & 7 & $\$ 16,130$ & $\$ 10,529$ & $\$ 843$ & $\$ 1136$ & $\$ 6554$ & $\$ 7865$ \\
Average & & $\$ 47,233$ & $\$ 36,490$ & $\$ 1227$ & $\$ 2480$ & $\$ 13,067$ & $\$ 16,235$ \\
\hline
\end{tabular}

consumer products, technology, industrial, and healthcare sectors each accounted for $15 \%$ to $17 \%$ of the sample. The oil and gas and financial segments were $12 \%$ and $11 \%$ of the total, while the utility, retail, and transportation sectors were $6 \%, 5 \%$, and $2 \%$ of the total. As a robustness check we will interact the industries with merger and divestiture announcement to test whether any one industry is biasing the results.

From Table 1 we see the highest average salaries among sampled firms are paid in the consumer industry, followed by the retail industry. One of the commonalities between these two industries is that they are relatively non-cyclical. The cyclical industries, such as oil and gas, industrial, and technology industries each pay lower salaries but higher stock and option compensation, as shown in TDC 1 and TDC 2. Companies in the financial sector are the largest as measured by market capitalization, while companies in the utility and transport sectors maintained the lowest market capitalization. The retail sector had the highest compensation using TDC 1 and TDC 2, as well as total current compensation.

Figure 1 shows annual pay by compensation category over the sample period. Here we see increasing compensation for all categories over the first three (2003-2005) to six years (2003-2008) of the sample. A sharp decline in the compensation level in each of the categories, except salaries, then occurs between 2006 and 2008. The compensation categories that include stock and option grants (TDC 1 and TDC 2) show a time trend similar to overall stock market performance over the period: rising through the first half of the decade and then declining in the years leading up to and including the recession of 2008/2009, before recovering around 2010. TDC 2 declined particularly sharply since this compensation category includes stock options exercised, and is therefore closely tied to contemporaneous market performance. TDC 1 declined more gradually, as TDC 1 includes stock options awarded. We also see in Figure 1 that average salary increased slightly (from $\$ 1.0$ million to $\$ 1.3$ million), while total current compensation 
(salary plus bonus) actually fell between 2003 and 2012. In contrast with the decline in TDC 2, which is sharpest in 2008, the declines in total current compensation and TDC 1 begin in 2006, preceding the recession.

Figure 2 shows the annual number of merger announcements and divestitures, while Figure 3 shows the average transaction value of merger announcements and divestitures. We see from Figure 2 that merger announcements increased for the first three years of the sample period and then declined over the last four years of the sample (2009-2012) to the 2003/2004 level. Divestiture announcements remained steady between two and five for the first six years of the sample and, like merger announcements, declined significantly in 2009. There were then a large number of divestitures that occurred in 2011.

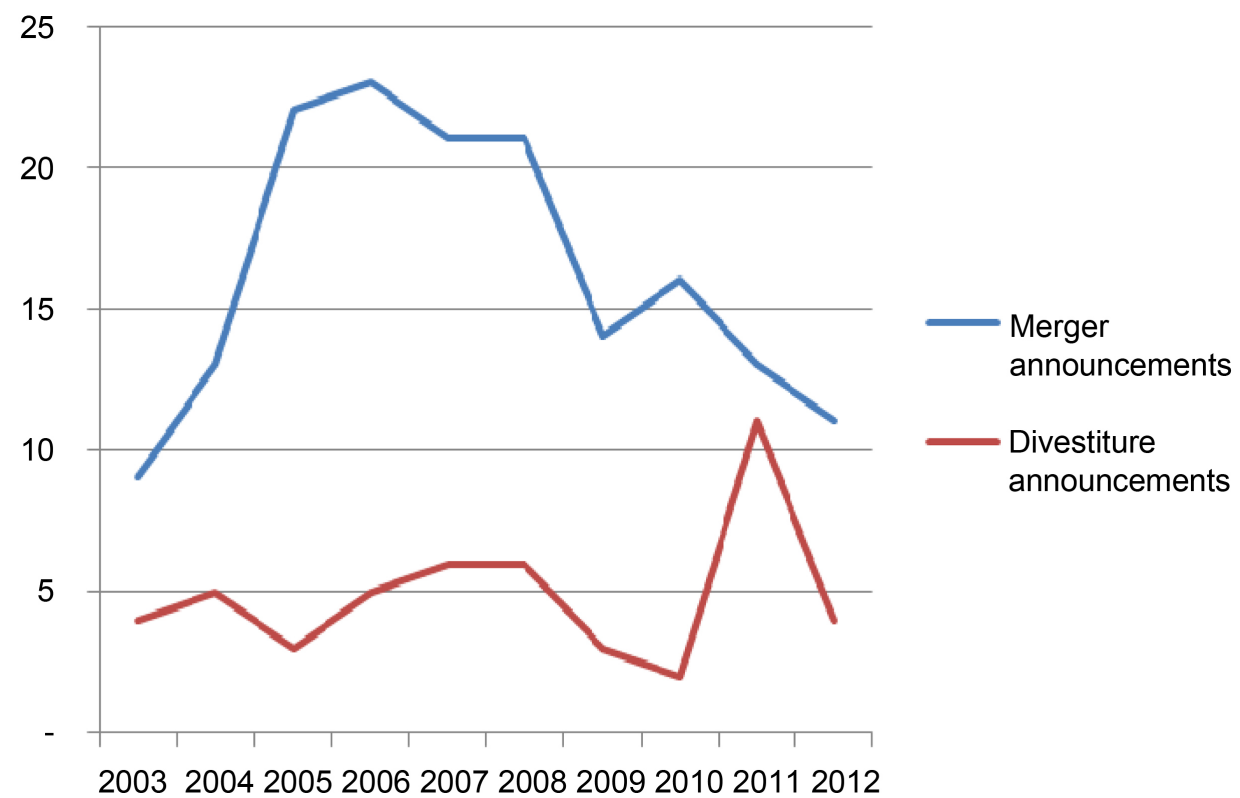

Figure 2. Annual merger and divestiture announcements.

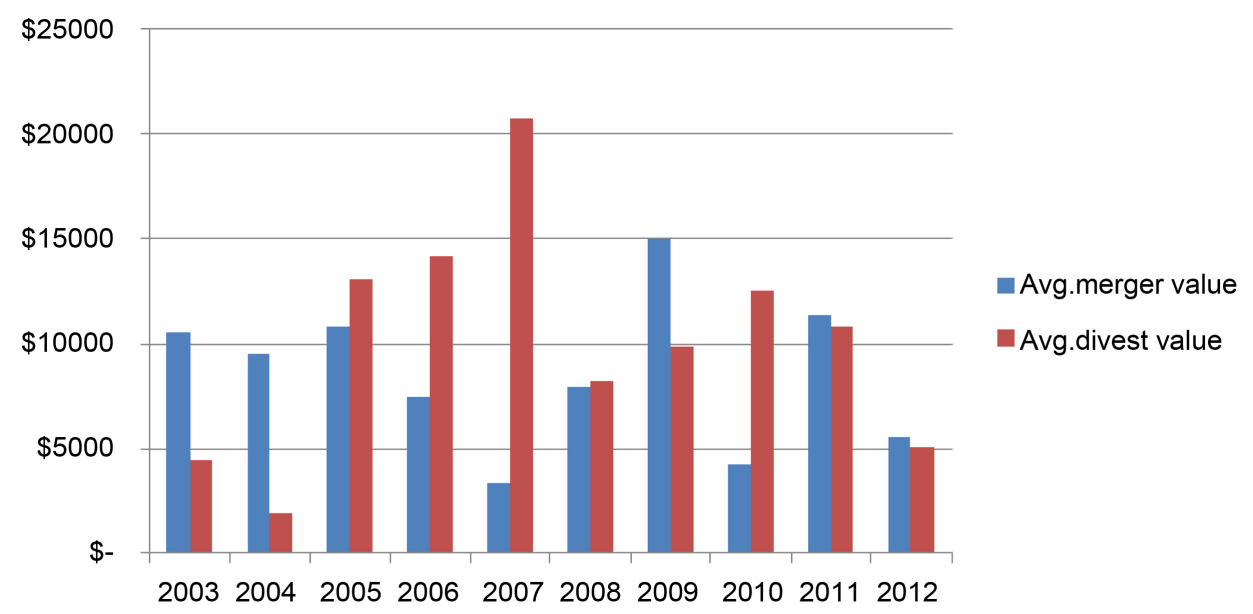

Figure 3. Merger and divestiture value by year. 
Table 2 shows the total number of mergers and divestitures by industry as well as the average and relative merger value by industry. Here we see that the largest number of mergers occurred in the technology industry, while the highest merger values occurred in the financial industry. Also, we observe that the high relative merger value (merger value/market capitalization) occurred in the utility sector. Regarding divestitures, we see that the consumer sector accounted for the largest number and largest value of divestitures.

From Figure 3 we see that, in addition to the growing number of mergers between 2003 and 2005, the average merger value was also growing larger. Merger value then declined but rose sharply in 2008 and 2009, suggesting few large mergers were announced in the recession years.

Figure 4 shows CEO board composition by year. There is a gradual but sustained trend toward more independent board membership over the period, as the average fraction of independent members rises from $70 \%$ to $85 \%$. This rise is made possible by a steady decline in both employee and affiliated board members over the ten years.

These trends in CEO compensation and board composition are confirmed in Table 3 , which shows the averages pre and post financial crisis. From Table 3 we see that the average market capitalization decreased while the average firm sales increased. In addition, we observe that $11.6 \%$ of CEOs were newly hired in any given year, but this amount declined from $13 \%$ to $10 \%$ pre versus post financial crisis. In contrast, the number of outside versus inside hires increased post financial crisis from $13 \%$ to $20 \%$. The change in each of these statistics will be explored further through our econometric modeling.

Finally, in Table 4 we segment each of the statistics between merging/divesting and non-merging firms. Here, we see the average non-merging/divesting firms in our sample were smaller than the merging/divesting firms. Accordingly, CEO compensation

Table 2. Merger summary statistics.

\begin{tabular}{ccccccccc}
\hline Industry & $\begin{array}{c}\text { Number } \\
\text { of } \\
\text { Mergers }\end{array}$ & $\begin{array}{c}\text { Average } \\
\text { Merger } \\
\text { Size (in } \\
\text { millions) }\end{array}$ & $\begin{array}{c}\text { Relative } \\
\text { Merger }\end{array}$ & $\begin{array}{c}\text { Merger } \\
\text { Size } \\
\text { Stand. } \\
\text { Dev. }\end{array}$ & $\begin{array}{c}\text { Number } \\
\text { of } \\
\text { Divest. }\end{array}$ & $\begin{array}{c}\text { Average } \\
\text { Divestiture } \\
\text { Size (in } \\
\text { millions) }\end{array}$ & $\begin{array}{c}\text { Relative } \\
\text { Divest. } \\
\text { Size }\end{array}$ & $\begin{array}{c}\text { Divest. } \\
\text { size } \\
\text { stand. } \\
\text { dev. }\end{array}$ \\
\hline Consumer & 22 & $\$ 9132$ & $20 \%$ & $\$ 1801$ & 13 & $\$ 18,544$ & $9 \%$ & $\$ 8345$ \\
Technology & 40 & $\$ 6722$ & $11 \%$ & $\$ 2948$ & 3 & $\$ 8949$ & $3 \%$ & $\$ 2277$ \\
Industrial & 22 & $\$ 3453$ & $9 \%$ & $\$ 742$ & 7 & $\$ 8948$ & $6 \%$ & $\$ 594$ \\
Financial & 18 & $\$ 15,086$ & $20 \%$ & $\$ 4562$ & 8 & $\$ 2392$ & $5 \%$ & $\$ 494$ \\
Healthcare & 32 & $\$ 8231$ & $18 \%$ & $\$ 2432$ & 11 & $\$ 11,054$ & $4 \%$ & $\$ 7460$ \\
Oil and gas & 14 & $\$ 10,147$ & $17 \%$ & $\$ 3340$ & 6 & $\$ 7998$ & $4 \%$ & $\$ 3498$ \\
Retail & 8 & $\$ 8367$ & $25 \%$ & $\$ 4266$ & 2 & $\$ 3412$ & $7 \%$ & $\$ 1262$ \\
Transport & 3 & $\$ 1858$ & $13 \%$ & $\$ 570$ & 1 & $\$ 2400$ & $9 \%$ & - \\
Utility & 3 & $\$ 14,092$ & $87 \%$ & $\$ 5872$ & 2 & $\$ 10,131$ & $7 \%$ & $\$ 7831$ \\
$\underline{\underline{\text { Total }}}$ & $\underline{\underline{162}}$ & $\underline{\underline{\$ 8268}}$ & $\underline{\underline{18 \%}}$ & $\underline{\underline{\$ 1008}}$ & $\underline{\underline{49}}$ & $\underline{\underline{\$ 10,249}}$ & $\underline{\underline{5 \%}}$ & $\underline{\underline{\$ 2480}}$ \\
\hline
\end{tabular}


Table 3. Summary statistics-pre- and post-financial crisis.

\begin{tabular}{cccc}
\hline Category-averages & $\begin{array}{c}\text { Pre-Financial } \\
\text { Crisis }\end{array}$ & $\begin{array}{c}\text { Post-Financial } \\
\text { Crisis }\end{array}$ & Total \\
\hline Size (Market Cap, millions) & $\$ 54,288$ & $\$ 45,211$ & $\$ 49,573$ \\
Size (Sales) & $\$ 35,739$ & $\$ 41,899$ & $\$ 38,939$ \\
Salary (thousands) & $\$ 1160$ & $\$ 1259$ & $\$ 1211$ \\
Total Compensation & $\$ 3083$ & $\$ 1695$ & $\$ 2362$ \\
TDC1 & $\$ 12,837$ & $\$ 12,847$ & $\$ 12,842$ \\
TDC2 & $\$ 17,790$ & $\$ 15,007$ & $\$ 16,345$ \\
EPS & $\$ 3.12$ & $\$ 3.174$ & $\$ 3.149$ \\
Annual stock market return & $18.7 \%$ & $6.8 \%$ & $12.5 \%$ \\
IP & $75.1 \%$ & $83.3 \%$ & $79.4 \%$ \\
EP & $16.0 \%$ & $13.0 \%$ & $14.4 \%$ \\
LP & $8.9 \%$ & $3.7 \%$ & $6.2 \%$ \\
Inside & $13.8 \%$ & $20.3 \%$ & $17.2 \%$ \\
New Hire & $13.2 \%$ & $10.1 \%$ & $11.6 \%$ \\
Observations & 482 & 511 & 1003 \\
\hline
\end{tabular}

Table 4. Summary statistics—merging/divesting versus non-merging/divesting firms.

\begin{tabular}{ccc}
\hline Category-averages & $\begin{array}{c}\text { Merging/Divesting } \\
\text { Companies }\end{array}$ & $\begin{array}{c}\text { Non } \\
\text { merging/divesting } \\
\text { companies }\end{array}$ \\
\hline Size (Market Cap, millions) & $\$ 55,255$ & $\$ 16,791$ \\
Size (Sales) & $\$ 42,293$ & $\$ 16,017$ \\
Totary (thousands) Compensation & $\$ 1246$ & $\$ 1198$ \\
TDC1 & $\$ 2629$ & $\$ 1908$ \\
TDC2 & $\$ 14,091$ & $\$ 9135$ \\
EPS & $\$ 17,553$ & $\$ 11,171$ \\
Net stock market return & 3.15 & 3.32 \\
IP & $5.8 \%$ & $11.1 \%$ \\
EP & $79 \%$ & $81 \%$ \\
LP & $14 \%$ & $15 \%$ \\
\hline
\end{tabular}

among the non-merging/divesting firms was less in each pay category.

\subsection{Empirical Strategy}

Our first set of results are based on variations on the estimation equation below, where $y_{j t}$ represents logged compensation for the CEO at firm $j$ in year $t$. The righthand side includes suite of regressors (described below), an indicator for the post-crisis period (2008 or later), and industry fixed effects $\mu_{k}$. The estimation is based on a panel data 


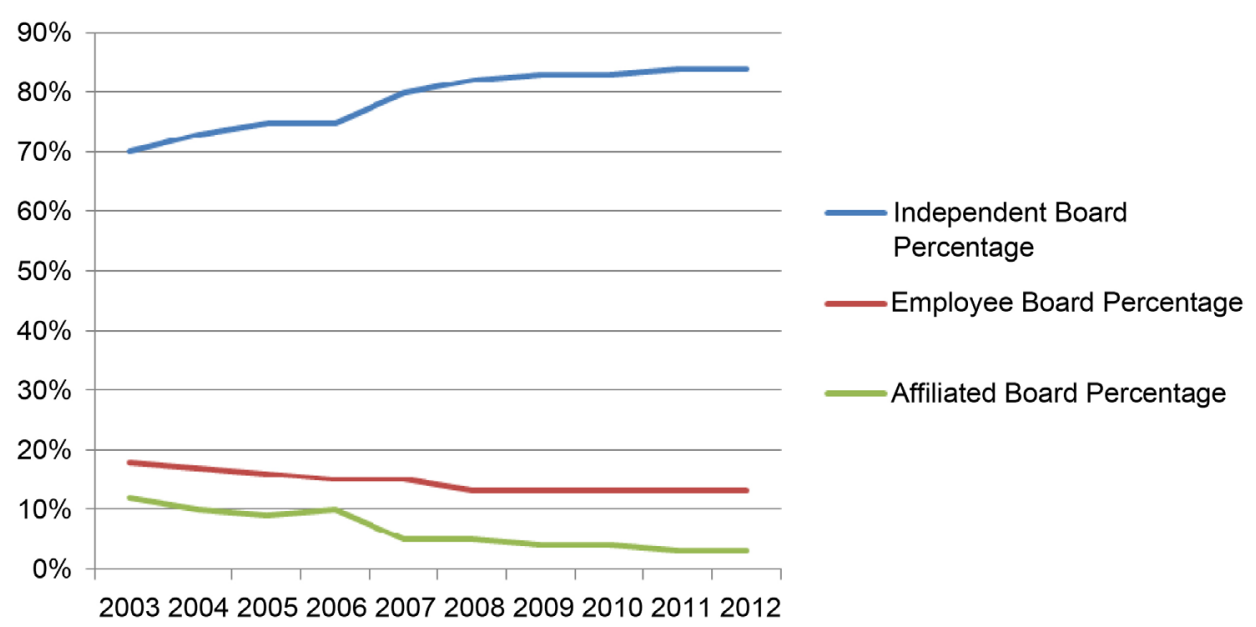

Figure 4. Board composition percentage by year.

model with random effects. (A Hausman test does not reject random effects in favor of fixed effects.)

$$
\begin{aligned}
y_{j t}= & \beta_{1} \text { Size }_{j, t-1}+\beta_{2} \text { Perf }_{j, t-1}+\beta_{3} \text { Board }_{j t}+\beta_{4} \text { Trans }_{j t} \\
& +\beta_{5} X_{j t}+\gamma \text { PostCrisis }_{t}+\mu_{k}+\epsilon_{j t}
\end{aligned}
$$

Separate regressions were run for each of the four executive compensation measures. Size $_{j, t-1}$ is the firm's (lagged) log sales. ${ }^{6} \quad \operatorname{Perf}_{j, t-1}$ is a vector of lagged firm performance measures; it includes log earnings per share, stock market return, and (for benchmarking) the S\&P return. The pair of variables Board $_{j t}=\left[\right.$ Indep $_{j t}$, Affil $\left._{j t}\right]$ includes the fraction of board members who are independent or affiliated; the fraction of employee board members is the omitted category.

The vector Trans ${ }_{j t}$ includes variables related to transactions (mergers and divestitures). Only large transactions (value of $\$ 1$ billion or greater) are considered. For mergers, the variables include MergerAnnouncement $t_{j t}$ (an indicator for announcing a large merger) and MergerPercentage $_{j t}$ (the transaction value of any large mergers as a fraction of the firm's market capitalization at the time of the announcement). Similarly, we have DivestitureAnnouncement ${ }_{j t}$ and DivestiturePercentage ${ }_{j t}$ for divestitures. We also include an indicator variable AnyDeals ${ }_{j}$ for firms that carried out any large merger or divestiture over the entire time horizon of our sample.

Finally, $x_{j t}$ is a vector of indicator variables specifying whether the current $\mathrm{CEO}$ was an outside hire, whether he or she is a new hire in year $t$, and an interaction of these two.

Specification (I) allows for a break in the level of compensation after the crisis, but otherwise it treats the coefficients on factors influencing pay as constant over time. This establishes a benchmark for comparison with other studies of the determinants of CEO pay. However, our conjecture is that the relationship between pay and the right hand side variables changed after the crisis. To test this, we estimate Specification (II) which ${ }^{6} \mathrm{We}$ also tested a specification using market capitalization for firm size (unreported). The results were similar, and the specification with sales has somewhat better fit. 
includes all of the regressors in Specification (I) but adds interactions between the PostCrisis $_{t}$ dummy and most of the regressors.

Finally, we conjecture that CEOs are rewarded differently for deal making across different industries. To test this, we estimate Specification (III) which includes all the regressors in Specification (I) and adds interactions between the MergerAnnouncement ${ }_{j t}$ variable and a firm's industry. ${ }^{7}$

\section{Results}

Table 5 shows the results for Specification (I). Recall that lagged sales and EPS are logged so their parameter estimates may be interpreted as elasticities. Like the rest of the literature we find strong, significant effects of firm size (on all measures of compensation except base salary). The coefficients, ranging from elasticities of 0.13 to 0.29 , match the range found in other studies. ${ }^{8}$ We find merger announcements to have a positive, significant effect on CEO compensation as measured by TDC 1 and TDC 2 . We also find divestiture announcements to have a positive and weakly significant effect on TDC 2. These results suggest that making the announcement (merger or divestiture) likely has a positive effect on the firm's stock market performance and, therefore, a positive effect on TDC 1 and TDC 2 for merger announcements. We do not, however, find relative merger value or divestiture value to affect CEO compensation; our findings relative to merger value contrasts with Hartford and $\mathrm{Li}$ (2007), Grinstein and Hribar (2004), and Yim (2013) perhaps due to different time periods being studied. Our findings relative to divestiture value are consistent with Bebchuk and Grinstein (2005) and Haynes et al. (2007).

Board composition also matters, but not exactly in the way that is usually thought (and not in the way proposed in Hypothesis 3). Boards with a higher fraction of outside directors compared to employee directors are associated with significantly higher salary and total cash compensation (but not higher TDC 1 or TDC 2 ). ${ }^{9}$ It does not appear to matter whether outsiders are independent or affiliated, as the coefficients on the two groups are almost identical. For total compensation, the magnitude corresponds to a $14 \%-16 \%$ pay increase if one seat on a ten-member board switches from an employee to an outsider. This could be evidence that outside directors, even those who are nominally independent, are beholden to the CEO, or that outside directors are distracted by other obligations and exert less stringent oversight. However, this result could also be rationalized within an optimal contracting framework if firm insiders (employees) are able to directly monitor a CEO's effort but outsiders must rely on noisier outcome measures. With noisier measures of effort and a risk-averse CEO, it may be optimal for outside directors to settle for lower-powered incentives and shift more of the CEO's compensation into cash.

${ }^{7}$ Divestitures were omitted, as there were not enough divestitures in the sample to precisely estimate industry-specific divestiture effects.

${ }^{8}$ See Kostiuk (1989) and Murphy (1985), among others.

${ }^{9}$ While this result runs counter to recent results about board independence, it is broadly consistent with the earlier results of Crystal (1991) Lambert et al. (1993) and Boyd (1994). 
Table 5. Regression results.

\begin{tabular}{|c|c|c|c|c|}
\hline Variables & (1) lsalary & (2) ltotal & (3) $\operatorname{ltdcl}$ & (4) $\operatorname{ltdc} 2$ \\
\hline \multirow[t]{2}{*}{ (log) lag_sales } & 0.0732 & $0.129^{* * *}$ & $0.260^{\star * *}$ & $0.230^{\star * *}$ \\
\hline & $(0.0479)$ & $(0.0463)$ & $(0.0417)$ & $(0.0496)$ \\
\hline Merger Value & -0.152 & -0.196 & -0.0489 & -0.255 \\
\hline Percentage & $(0.373)$ & $(0.365)$ & $(0.179)$ & $(0.235)$ \\
\hline \multirow[t]{2}{*}{ Merger announcement } & 0.211 & 0.190 & $0.194^{* * *}$ & $0.179^{* *}$ \\
\hline & $(0.140)$ & $(0.137)$ & $(0.0686)$ & $(0.0902)$ \\
\hline Divestiture Value & 0.109 & 0.203 & 0.0794 & -0.0318 \\
\hline Percentage & $(0.288)$ & $(0.281)$ & $(0.141)$ & $(0.186)$ \\
\hline Divestiture & 0.202 & 0.135 & 0.0483 & $0.386^{*}$ \\
\hline announcement & $(0.349)$ & $(0.342)$ & $(0.174)$ & $(0.229)$ \\
\hline \multirow[t]{2}{*}{ New Hire } & 0.0541 & -0.0454 & -0.0305 & -0.0353 \\
\hline & $(0.153)$ & $(0.148)$ & $(0.1000)$ & $(0.127)$ \\
\hline \multirow[t]{2}{*}{ Outside } & $-0.305^{\star *}$ & $-0.333^{\star *}$ & $-0.342^{* * *}$ & $-0.548^{\star * *}$ \\
\hline & $(0.148)$ & $(0.145)$ & $(0.0720)$ & $(0.0946)$ \\
\hline \multirow[t]{2}{*}{ New_Outsider } & -0.0798 & 0.222 & $0.286^{\star *}$ & $0.356^{\star *}$ \\
\hline & $(0.279)$ & $(0.273)$ & $(0.137)$ & $(0.180)$ \\
\hline Firm Type (Merged/ & 0.0536 & 0.184 & -0.0963 & -0.0655 \\
\hline No Merger) & $(0.145)$ & $(0.140)$ & $(0.140)$ & $(0.164)$ \\
\hline \multirow[t]{2}{*}{ Independent Percentage } & $2.537^{\star * *}$ & $1.463^{* *}$ & -0.335 & -0.448 \\
\hline & $(0.714)$ & $(0.694)$ & $(0.399)$ & $(0.516)$ \\
\hline \multirow[t]{2}{*}{ Affiliated Percentage } & $2.775^{\star \star *}$ & $1.756^{* *}$ & -0.138 & -0.541 \\
\hline & $(0.871)$ & $(0.848)$ & $(0.457)$ & $(0.593)$ \\
\hline \multirow[t]{2}{*}{ Financial Crisis } & -0.133 & -0.165 & $-0.217^{\star * *}$ & $-0.451^{* * *}$ \\
\hline & $(0.169)$ & $(0.166)$ & $(0.0809)$ & $(0.107)$ \\
\hline \multirow[t]{2}{*}{ Lag EPS } & $0.0594^{\star * *}$ & $0.0542^{\star * *}$ & $0.0304^{\star * *}$ & $0.0349^{* * *}$ \\
\hline & $(0.0187)$ & $(0.0183)$ & $(0.0101)$ & $(0.0131)$ \\
\hline \multirow[t]{2}{*}{ Lag Firm stock perf. } & $0.538^{\star * *}$ & $0.628^{* * *}$ & $0.277^{\star * *}$ & $0.492^{* * *}$ \\
\hline & $(0.156)$ & $(0.153)$ & $(0.0758)$ & $(0.0997)$ \\
\hline \multirow[t]{2}{*}{ Lag S\&P performance } & $-0.497^{\star}$ & -0.239 & 0.0994 & -0.0844 \\
\hline & $(0.274)$ & $(0.268)$ & $(0.131)$ & $(0.172)$ \\
\hline \multirow[t]{2}{*}{ Time trend } & 0.00236 & $-0.0920^{\star * *}$ & $0.0677^{\star * *}$ & $0.102^{* * *}$ \\
\hline & $(0.0318)$ & $(0.0312)$ & $(0.0154)$ & $(0.0202)$ \\
\hline \multirow[t]{2}{*}{ Constant } & $3.618^{* * *}$ & $5.026^{* * *}$ & $5.785^{\star * *}$ & $6.262^{* * *}$ \\
\hline & $(0.751)$ & $(0.727)$ & $(0.641)$ & $(0.758)$ \\
\hline Industry effects & Yes & Yes & Yes & Yes \\
\hline Observations & 870 & 870 & 887 & 887 \\
\hline R-squared & 0.136 & 0.172 & 0.292 & 0.235 \\
\hline Number of entities & 113 & 113 & 115 & 115 \\
\hline
\end{tabular}

Robust standard errors in parentheses: ${ }^{* * *} \mathrm{p}<0.01,{ }^{* *} \mathrm{p}<0.05,{ }^{*} \mathrm{p}<0.1$. 
Firm performance, as measured by lagged earnings per share and stock returns, is a highly significant predictor of pay for all four measures of compensation. A negative coefficient on lagged S\&P returns would indicate some benchmarking of firm performance relative to the overall market; there is some weak evidence of this for cash compensation but none at all for TDC 1 and TDC 2 .

Finally, we find that across all compensation measures new hires are paid less (by around $26 \%$ - 42\%) than incumbent CEOs. ${ }^{10}$ While there is no overall difference in pay between CEOs who were hired from inside or outside the firm, newly hired outsiders receive a premium on TDC 1 and TDC 2 (relative to newly hired insiders) that comes close to erasing the disadvantage of being a new hire.

In this specification, there is evidence for a downward shift in the level of compensation after the financial crisis. The coefficients for TDC 1 and TDC 2 are negative and significant indicating that variable compensation as measured by TDC 1 and TDC 2 declined by $20 \%-26 \%$. The coefficients for salary and total compensation were also negative but not significant. To investigate the effect of the financial crisis on CEO compensation further, we considered the post-crisis changes in the testable variables on CEO pay, delineated in Specification (II).

Results for Specification (II) are presented in Table 6. Our first point concerns the direct effect of the post-crisis dummy. In this specification we see substantial level changes in compensation after the crisis when we allow for a structural break in the other coefficients. Salary declines substantially, while TDC 1 rises. (TDC 2 rises while total compensation falls, but not significantly.) This suggests that, holding other factors constant, the composition of pay shifted away from cash and toward incentive pay (equity and options). The rise in TDC 1 is somewhat surprising, as one might have expected some mechanical decline in the value of equity-based compensation as stock prices fell. One possible explanation would be a countervailing increase in the volume of such grants post-crisis, perhaps with the intention of keeping CEOs more accountable for performance.

The second main observation concerns a shift in the factors most closely associated with CEO pay-in broad terms, performance measures related to shareholder value matter more post-crisis and other factors matter less. On the performance side, the pre-crisis evidence that CEOs are rewarded for EPS and stock returns is mixed at best. (There are significant positive effects for EPS on TDC 1 and stock returns on TDC 2. However, coefficients on both performance measures rise uniformly after the crisis, and this change (the coefficient on the interaction terms) is significant in six of eight cases (both cash compensation measures and TDC 2 for EPS, and salary, total compensation, and TDC 1 for stock returns). Consequently, for both EPS and stock returns, the overall post-crisis effect of performance (that is, the pre-crisis coefficient plus the interaction term) is positive and significant for every type of CEO Compensation. Overall, the evidence suggests that $\mathrm{CEO}$ compensation became more strongly linked to firm performance after the financial crisis.

${ }^{10}$ As pointed out by Murphy (2002), one possible explanation is that only partial-year compensation may be reported in the year of the new hire. 
Table 6. Regression results-financial crisis effect.

\begin{tabular}{|c|c|c|c|c|}
\hline Variables & (1) lsalary & (2) ltotal & (3) $\operatorname{ltdc} 1$ & (4) $\operatorname{ltdc} 2$ \\
\hline \multirow[t]{2}{*}{ (log) lag_sales } & $0.158^{* * *}$ & $0.289^{* * *}$ & $0.313^{\star * *}$ & $0.312^{\star * *}$ \\
\hline & $(0.0591)$ & $(0.0558)$ & $(0.0458)$ & $(0.0531)$ \\
\hline (log) lag_sales & $-0.218^{* * *}$ & $-0.339^{* * *}$ & $-0.151^{\star * *}$ & $-0.172^{\star * *}$ \\
\hline${ }^{\star}$ Financial Crisis & $(0.0683)$ & $(0.0651)$ & $(0.0351)$ & $(0.0471)$ \\
\hline Merger Value & -0.644 & -0.437 & -0.0699 & -0.683 \\
\hline Percentage & $(0.720)$ & $(0.685)$ & $(0.359)$ & $(0.483)$ \\
\hline \multirow[t]{2}{*}{ Merger announcement } & 0.274 & 0.101 & 0.148 & 0.178 \\
\hline & $(0.188)$ & $(0.179)$ & $(0.0959)$ & $(0.129)$ \\
\hline Merger Announcement & -0.235 & 0.117 & 0.119 & 0.0794 \\
\hline${ }^{\star}$ Financial Crisis & $(0.284)$ & $(0.271)$ & $(0.145)$ & $(0.196)$ \\
\hline Divest Value & 0.236 & 0.277 & 0.0518 & -0.0702 \\
\hline Percentage & $(0.280)$ & $(0.267)$ & $(0.144)$ & $(0.194)$ \\
\hline Divestiture & 0.129 & 0.106 & 0.0448 & $0.437^{*}$ \\
\hline announcement & $(0.346)$ & $(0.329)$ & $(0.182)$ & $(0.243)$ \\
\hline \multirow[t]{2}{*}{ Independent Perc } & 0.271 & -0.215 & 0.0738 & -0.643 \\
\hline & $(0.838)$ & $(0.795)$ & $(0.466)$ & $(0.613)$ \\
\hline \multirow[t]{2}{*}{ Affiliated Perc } & 0.133 & -0.354 & 0.416 & -0.821 \\
\hline & $(1.018)$ & $(0.967)$ & $(0.537)$ & $(0.711)$ \\
\hline Independent Perc & $5.962^{* * *}$ & $5.050^{* * *}$ & -0.306 & 1.116 \\
\hline${ }^{\star}$ Financial Crisis & $(1.131)$ & $(1.077)$ & $(0.578)$ & $(0.774)$ \\
\hline Affiliated Perc & $7.050^{* * *}$ & $6.165^{\star * *}$ & -0.513 & 1.719 \\
\hline${ }^{\star}$ Financial Crisis & $(1.579)$ & $(1.502)$ & $(0.835)$ & $(1.111)$ \\
\hline \multirow[t]{2}{*}{ Financial Crisis } & $-3.607^{* * *}$ & -1.361 & $1.502^{* * *}$ & 0.101 \\
\hline & $(0.986)$ & $(0.939)$ & $(0.495)$ & $(0.665)$ \\
\hline \multirow[t]{2}{*}{ New_HIRE } & $-0.329^{\star *}$ & $-0.361^{* * *}$ & $-0.359^{* * *}$ & $-0.595^{\star * *}$ \\
\hline & $(0.144)$ & $(0.137)$ & $(0.0733)$ & $(0.0984)$ \\
\hline \multirow[t]{2}{*}{ Outside } & 0.0402 & -0.0697 & 0.00616 & -0.00661 \\
\hline & $(0.159)$ & $(0.150)$ & $(0.104)$ & $(0.132)$ \\
\hline \multirow[t]{2}{*}{ New Outsider } & 0.222 & $0.569^{* *}$ & $0.283^{* *}$ & $0.375^{* *}$ \\
\hline & $(0.273)$ & $(0.260)$ & $(0.140)$ & $(0.188)$ \\
\hline Firm Type (Merged/ & 0.0277 & 0.150 & -0.0987 & -0.0440 \\
\hline No Merger) & $(0.152)$ & $(0.143)$ & $(0.146)$ & $(0.160)$ \\
\hline \multirow[t]{2}{*}{ Lag EPS } & -0.00421 & -0.0364 & $0.0344^{* *}$ & 0.0161 \\
\hline & $(0.0284)$ & $(0.0270)$ & $(0.0152)$ & $(0.0202)$ \\
\hline Lag EPS & $0.128^{* * *}$ & $0.177^{\star * *}$ & 0.00533 & $0.0398^{\star}$ \\
\hline${ }^{\star}$ Financial Crisis & $(0.0328)$ & $(0.0312)$ & $(0.0170)$ & $(0.0228)$ \\
\hline \multirow[t]{2}{*}{ Lag Firm stock perf. } & -0.385 & 0.304 & 0.0183 & $0.345^{\star}$ \\
\hline & $(0.274)$ & $(0.261)$ & $(0.139)$ & $(0.187)$ \\
\hline
\end{tabular}




\section{Continued}

\begin{tabular}{ccccc}
\hline Lag Firm stock perf. & $1.396^{* * *}$ & $0.563^{*}$ & $0.317^{* *}$ & 0.119 \\
^Financial Crisis & $(0.315)$ & $(0.300)$ & $(0.160)$ & $(0.215)$ \\
Lag S\&P perf. & $-0.861^{* * *}$ & -0.271 & 0.0974 & -0.0299 \\
Time trend & $(0.273)$ & $(0.261)$ & $(0.137)$ & $(0.185)$ \\
& -0.0393 & $-0.189^{* * *}$ & $0.0574^{* * *}$ & $0.0963^{* * *}$ \\
Constant & $(0.0388)$ & $(0.0370)$ & $(0.0197)$ & $(0.0264)$ \\
& $5.232^{* * *}$ & $5.578^{* * *}$ & $5.008^{* * *}$ & $5.805^{* * *}$ \\
Industry effects & $(0.905)$ & $(0.855)$ & $(0.709)$ & $(0.817)$ \\
Observations & Yes & Yes & Yes & Yes \\
R-squared & 769 & 769 & 786 & 785 \\
Number of entities & 0.207 & 0.257 & 0.322 & 0.256 \\
\hline
\end{tabular}

Robust standard errors in parentheses: ${ }^{* *} \mathrm{p}<0.01,{ }^{* *} \mathrm{p}<0.05,{ }^{*} \mathrm{p}<0.1$.

Next we consider a factor in pay that is more tenuously related to shareholder value: firm size. The pre-crisis effect of firm size ranges from elasticities of 0.16 to 0.32 and is strongly significant for every measure of compensation. However, this effect diminishes significantly (for all four compensation measures) after the crisis. For salary and total compensation, this decline wipes out the entire effect of firm size- the post-crisis elasticities are -0.06 and -0.05 and not statistically significant. For TDC 1 and TDC 2, the effect of firm size is roughly halved (declines of $48 \%$ and $55 \%$ ), with post-crisis elasticities of 0.16 and 0.14 . One interpretation, consistent with the results about firm performance, is that the crisis had a sobering effect that induced boards to sharpen their focus on rewarding outcomes more closely related to shareholder value. Note (see Table 4) that average sales are higher in the post-crisis period than before. Thus a more cynical interpretation of the weaker post-crisis coefficients on firm size-that boards reward CEOs for sales during booms but do not punish them for falling sales when times are harder-does not appear to be consistent with the data.

The third main point has to do with board composition. Recall that the salient fact over the entire time period was that non-employee directors (whether independent or affiliated) are associated with higher salary and total compensation. In Table 6, we see that this entire effect is concentrated in the post-crisis period. Before the crisis, coefficients on the fraction of outside directors are small and insignificant. However, after the crisis outside boards with more outside directors award significantly larger salaries and total compensation. The size of this effect is rather substantial. Revisiting an example from earlier, switching one seat on a ten-member board from an outsider to an employee would be associated with $40 \%-46 \%$ lower total compensation for the CEO in the post-crisis period. We cannot be sure why this is the case; one possibility is that employee board members were more attuned to the potential benefits (morale, optics, and so forth) of having the CEO share the pain of a downturn.

Regarding mergers and divestitures, we do not find evidence of differential effects 
regarding the merger announcement or relative merger value, pre versus post financial crisis. We also do not find any differential effects regarding divestiture value, pre versus post financial crisis. ${ }^{11}$

Finally, as a robustness check, we turn to Specification (III) which examines the influence of industry interacted with merger and divestiture announcement on CEO compensation. From these results (see Table 7) we see that the coefficients for divestiture announcements interacted with utilities was positive and weakly significant when regressed against TDC 2 . No other coefficients for merger or divestiture announcements were significant. As such, it does not appear that there is much industry bias in the merger or divestiture effect on CEO compensation.

Table 7. Regression results-industries interacted with merger value percentage.

\begin{tabular}{|c|c|c|c|c|}
\hline Variables & (1) lsalary & (2) ltotal & (3) $\operatorname{ltdc} 1$ & (4) $\operatorname{ltdc} 2$ \\
\hline Merger & -0.0675 & -0.0752 & 0.0583 & -0.244 \\
\hline Value Percentage & $(0.404)$ & $(0.392)$ & $(0.189)$ & $(0.248)$ \\
\hline Merger & -0.409 & 0.408 & 0.411 & 0.546 \\
\hline Announcement & $(1.232)$ & $(1.194)$ & $(0.584)$ & $(0.766)$ \\
\hline Divest & 0.275 & 0.415 & 0.0213 & -0.147 \\
\hline Value Percentage & $(0.315)$ & $(0.306)$ & $(0.152)$ & $(0.200)$ \\
\hline Divest & -0.00651 & 0.503 & 0.719 & -0.324 \\
\hline Announcement & $(1.231)$ & $(1.194)$ & $(0.583)$ & $(0.765)$ \\
\hline \multicolumn{5}{|c|}{ Industry Interactions } \\
\hline \multicolumn{5}{|c|}{ Merger Announcement* } \\
\hline \multirow[t]{2}{*}{ Finance } & 0.565 & -0.307 & 0.123 & -0.407 \\
\hline & $(1.288)$ & $(1.249)$ & $(0.611)$ & $(0.801)$ \\
\hline \multirow[t]{2}{*}{ Oil and Gas } & 0.380 & -0.301 & -0.0518 & -0.149 \\
\hline & $(1.282)$ & $(1.243)$ & $(0.608)$ & $(0.797)$ \\
\hline \multirow[t]{2}{*}{ Industrial } & 0.622 & -0.519 & -0.375 & -0.511 \\
\hline & $(1.269)$ & $(1.231)$ & $(0.604)$ & $(0.792)$ \\
\hline \multirow[t]{2}{*}{ Health Care } & 0.630 & -0.344 & -0.242 & -0.515 \\
\hline & $(1.259)$ & $(1.220)$ & $(0.598)$ & $(0.785)$ \\
\hline \multirow[t]{2}{*}{ Technology } & 0.463 & -0.135 & -0.261 & -0.325 \\
\hline & $(1.252)$ & (1.214) & $(0.596)$ & $(0.781)$ \\
\hline \multirow[t]{2}{*}{ Consumer } & 0.733 & -0.0541 & -0.320 & -0.213 \\
\hline & $(1.276)$ & (1.238) & $(0.607)$ & $(0.797)$ \\
\hline \multirow[t]{2}{*}{ Utility } & 0.714 & -0.212 & -0.913 & -0.783 \\
\hline & $(1.747)$ & (1.694) & $(0.687)$ & $(0.901)$ \\
\hline \multirow[t]{2}{*}{ Retail } & 0.498 & -0.616 & -0.195 & -0.161 \\
\hline & 0.565 & -0.307 & 0.123 & -0.407 \\
\hline
\end{tabular}

${ }^{11} \mathrm{We}$ were not able to test the effect of divestiture announcements interacted with the financial crisis due to multi-collinearity. 


\section{Continued}

Divest Announcement*

Finance

Oil and Gas

Industrial

Health Care

Technology

Consumer

Utility

ther Regressors

(log) lag_sales

Inside

New_HIRE

Inside_New

Firm Type

(Merged_Nomerge)

Independent Perc

Affiliated Perc.

Financial crisis

Lag Firm stock perf.

Lag S\&P perf.
0.641

(1.421)

$-0.226$

(1.388)

$-0.0445$

(1.391)

0.0550

(1.424)

$-0.295$

(1.540)

0.203

(1.314)

$-0.233$

(1.740)

(1)

0.0577

(0.0445)

0.0428

(0.150)

$-0.316^{\star *}$

(0.154)

$-0.128$

$(0.287)$

0.136

(0.137)

$-2.127^{* * *}$

(0.693)

0.170

(0.577)

$-0.126$

(0.177)

$0.0717^{* * *}$

(0.0183)

$0.547^{* * *}$

(0.161)

$-0.500^{*}$

$(0.283)$
$-0.192$

(1.378)

$-0.828$

(1.347)

$-0.531$

(1.349)

$-0.699$

(1.381)

$-1.059$

(1.493)

$-0.627$

(1.274)

$-0.824$

(1.687)

(2)

$0.132^{* * *}$

(0.0438)

$-0.0170$

(0.147)

$-0.350^{\text {** }}$

(0.149)

0.179

(0.279)

$0.265^{\star *}$

(0.135)

$-0.950$

(0.678)

0.304

(0.562)

$-0.170$

(0.171)

$0.0619^{* * *}$

(0.0178)

$0.646^{* * *}$

(0.156)

$-0.253$

(0.274)
$-0.0172$

1.447

(0.674)

(0.884)

$-0.592$

1.197

(0.665)

(0.872)

$-0.589$

0.968

(0.667)

(0.874)

$-0.875$

0.00268

(0.675)

(0.886)

$-0.600$

0.497

(0.747)

(0.978)

$-0.698$

0.440

(0.624)

(0.819)

0.433

$1.781^{*}$

(0.717)

(0.941)

(3)

(4) 


\begin{tabular}{ccccc} 
Continued & & & \\
\hline Time_trend & 0.00293 & $-0.0892^{* * *}$ & $0.0700^{* * *}$ & $0.101^{* * *}$ \\
& $(0.0331)$ & $(0.0320)$ & $(0.0154)$ & $(0.0202)$ \\
Constant & $6.353^{* * *}$ & $6.346^{* * *}$ & $6.026^{* * *}$ & $6.297^{* * *}$ \\
& $(0.496)$ & $(0.487)$ & $(0.412)$ & $(0.507)$ \\
Observations & 869 & 870 & 887 & 887 \\
Number of entities & 113 & 113 & 115 & 115 \\
Adjusted R2 overall & 0.139 & 0.175 & 0.295 & 0.243 \\
\hline
\end{tabular}

Notes: Robust standard errors are in parentheses. ${ }^{* * *},{ }^{* *}$, and ${ }^{*}$ denote statistical significance levels of $1 \%, 5 \%$, and $10 \%$ respectively. MSE denotes means square error.

\section{Conclusions}

We examine the determinants of CEO compensation over a ten-year period spanning the 2008 financial crisis. While compensation fluctuated significantly over this ten-year time frame, average pay was essentially flat over this period. This finding marks a break with the rapid expansion in CEO pay found in the prior twenty years; however, the results are similar to the historical trend found by Frydman and Saks (2010).

The goal of this paper was to test the impact of the financial crisis on CEO compensation. In particular, we examined how the connection between compensation and factors such as firm performance, board composition, and mergers and divestitures changed between the pre- and post-crisis periods.

Consistent with other studies, we find an elasticity of compensation with respect to firm size of 0.08 to 0.29 , with a greater effect found when regressed against equity compensation. After accounting for firm size, merger value percentage was associated with CEO variable compensation, as measured by TDC 1 . There was also evidence that divestiture value percentage has a positive effect on CEO variable compensation (TDC 1 and TDC 2) after controlling for firm size. This finding is new and suggests that while divestitures lower firm size, CEOs are rewarded for disposing of assets that are likely underperforming. We also found evidence suggesting the divestiture effect to be impacted by industry, with high equity compensation associated with divestitures in the oil and gas, utility, and financial industries.

In addition, we found the financial crisis to have a significant impact on the structure of CEO compensation, with variable compensation preferred over cash payout. The explanation for this change may be that the pay for performance philosophy plays a larger role in guiding $\mathrm{CEO}$ compensation after the financial crisis, as shown in the relative significant effect that the financial performance variables had post financial crisis. In addition, board composition impacted CEO compensation, with a higher independent and affiliated percentages found to be associated with higher cash CEO compensation, measured by salary and total compensation. This effect was found to be significant only after the financial crisis.

In summary, the financial crisis appears to have altered the determinants of CEO compensation toward pay for performance. It is left to other studies to disentangle 
these effects further and assess how these factors cause CEO compensation to vary from various peer groups.

\section{Acknowledgements}

I am really grateful to the anonymous referees whose comments have significantly improved this paper.

\section{References}

[1] Core, J., Guay, W. and Larcker, D. (2003) Executive Equity Compensation and Incentives: A Survey. FRBNY Economic Policy Review, 9, 27-50.

[2] Frydman, C. and Saks, R. (2010) Executive Compensation: A New View from a Long-Term Perspective, 1936-2005. Review of Financial Studies, 23, 2099-2138.

http://dx.doi.org/10.1093/rfs/hhp120

[3] Core, J., Holthausen, R. and Larcker, D. (1999) Corporate Governance, Chief Executive Officer Compensation and Firm Performance. Journal of Financial Economics, 51, 371-406. http://dx.doi.org/10.1016/S0304-405X(98)00058-0

[4] Bebchuk, L. and Fried, J. (2003) Executive Compensation as an Agency Problem. Journal of Economic Perspectives, 17, 71-92. http://dx.doi.org/10.1257/089533003769204362

[5] Crystal, G. (1991) In Search of Excess: The Overcompensation of American Executives. WW Norton, New York.

[6] Lambert, R., Larcker, D. and Weigelt, K. (1993) The Structure of Organizational Incentives. Administrative Science Quarterly, 38, 438-461. http://dx.doi.org/10.2307/2393375

[7] Boyd, B.K. (1994) Board Control and CEO Compensation. Strategic Management Journal, 15, 335-344. http://dx.doi.org/10.1002/smj.4250150502

[8] Finkelstein, S. and Hambrick, D. (1989) Chief Executive Compensation: A Study of the Intersection of Markets and Political Processes. Strategic Management Journal, 10, 121-134. http://dx.doi.org/10.1002/smj.4250100203

[9] Conyon, M.J. (2006) Executive Compensation and Incentives. Academy of Management Perspectives, 20, 25-44. http://dx.doi.org/10.5465/AMP.2006.19873408

[10] Chhaochharia, V. and Grinstein, Y. (2009) CEO Compensation and Board Structure. Journal of Finance, 64, 231-260. http://dx.doi.org/10.1111/j.1540-6261.2008.01433.x

[11] Conyon, M.J. and He, L. (2004) Compensation Committees and CEO Compensation Incentives in US Entrepreneurial Firms. Journal of Management Accounting Research, 16, 35-56. http://dx.doi.org/10.2308/jmar.2004.16.1.35

[12] Boyle, G. and Roberts, H. (2013) CEO Presence on the Compensation Committee: A Puzzle. Journal of Economics and Business, 70, 16-26. http://dx.doi.org/10.1016/j.jeconbus.2012.08.002

[13] Sur, S., Magnan, M. and Cordeiro, J. (2015) Disentangling CEO Compensation: A Simultaneous Examination of Time, Industry, and Firm Level Effect. Canadian Journal of Administrative Sciences, 32, 30-46. http://dx.doi.org/10.1002/cjas.1304

[14] Murphy, K.J. (2002) Explaining Executive Compensation: Managerial Power versus the Perceived Cost of Stock Options. University of Chicago Law Review, 69, 847-869. http://dx.doi.org/10.2307/1600633

[15] Kostiuk, P.F. (1989) Firm Size and Executive Compensation. Journal of Human Resources, 25, 90-105. http://dx.doi.org/10.2307/145728

[16] Murphy, K.J. (1985) Corporate Performance and Managerial Remuneration. Journal of 
Accounting and Economics, 7, 11-42. http://dx.doi.org/10.1016/0165-4101(85)90026-6

[17] Gayle, G. and Miller, R. (2009) Has Moral Hazard Become a More Important Factor in Managerial Compensation? American Economic Review, 99, 1740-1769. http://dx.doi.org/10.1257/aer.99.5.1740

[18] Marris, R. (1964) The Economic Theory of "Managerial” Capitalism, Macmillan, London. http://dx.doi.org/10.1007/978-1-349-81732-0

[19] Aoki M. (1984) The Co-Operative Game Theory of the Firm. Oxford University Press, Oxford.

[20] Tosi, H., Werner, S., Katz, J. and Gomez, L. (2000) How Much Does Performance Matter. A Meta-Analysis of CEO Pay Studies. Journal of Management, 26, 301-339. http://dx.doi.org/10.1177/014920630002600207

[21] Rosen, S. (1992) Contracts and the Market for Executives. In: Werin, L. and Wijkander, H., Eds., Contract Economics, Blackwell, Cambridge, 181-211.

[22] Baker, G. and Hall, B. (2004) CEO Incentives and Firm Size. Journal of Labor Economics, 22, 767-798. http://dx.doi.org/10.1086/423154

[23] Gabaix, X. and Landier, A. (2008) Why Has CEO Pay Increased So Much? Quarterly Journal of Economics, 123, 49-100. http://dx.doi.org/10.1162/qjec.2008.123.1.49

[24] Moeller, S., Schlingemann, F. and Stulz, R. (2004) Firm Size and the Gains from Acquisitions. Journal of Financial Economics, 73, 201-228.

http://dx.doi.org/10.1016/j.jfineco.2003.07.002

[25] Harford, J. and Li, K. (2007) Decoupling CEO Wealth and Firm Performance: The Case of Acquiring CEOs. Journal of Finance, 62, 917-949. http://dx.doi.org/10.1111/j.1540-6261.2007.01227.x

[26] Grinstein, Y. and Hribar, P. (2004) CEO Compensation and Incentives: Evidence from M\&A Bonuses. Journal of Financial Economics, 73, 119-143. http://dx.doi.org/10.1016/j.jfineco.2003.06.002

[27] Yim, S. (2013) The Acquisitiveness of Youth: CEO Age and Acquisition Behavior. Journal of Financial Economics, 108, 250-273. http://dx.doi.org/10.1016/j.jfineco.2012.11.003

[28] Bebchuk, L. and Grinstein, Y. (2005) Firm Expansion and CEO Pay. NBER Working Paper 11886. http://www.nber.org/papers/w11886.pdf

[29] Haynes, M., Thompson, S. and Wright, M. (2007) Executive Remuneration and Corporate Divestment: Motivating Managers to Make Unpalatable Decisions. Journal of Business Finance and Accounting, 34, 792-818. http://dx.doi.org/10.1111/j.1468-5957.2007.02008.x

[30] Vemala, P., Nguyen, L., Nguyen, D. and Kommasani, A. (2014) CEO Compensation: Does Financial Crisis Matter? International Business Research, 7, 125-131. http://dx.doi.org/10.5539/ibr.v7n4p125

[31] Faulkender, M., Kadyrzhanova, D., Prdhala, N. and Sanbel, S. (2010) Executive Compensation: An Overview of Research on Corporate Practices and Proposed Reforms. Journal of Corporate Finance, 22, 107-118. http://dx.doi.org/10.1111/j.1745-6622.2010.00266.x

[32] Kaplan, S.N. and Joshua, R. (2010) Wall Street and Main Street: What Contributes to the Rise in the Highest Incomes? Review of Financial Studies, 23, 1004-1050. http://dx.doi.org/10.1093/rfs/hhp006

[33] Hallock, K.F. (1997) Reciprocally Interlocking Boards of Directors and Executive Compensation. Journal of Financial and Quantitative Analysis, 32, 331-343.

http://dx.doi.org/10.2307/2331203

[34] Fich, E.M. and White, L.J. (2003) CEO Compensation and Turnover: The Effects of Mutually Interlocked Boards. Wake Forest Law Review, 38, 935-959. 
Submit or recommend next manuscript to SCIRP and we will provide best service for you:

Accepting pre-submission inquiries through Email, Facebook, LinkedIn, Twitter, etc.

A wide selection of journals (inclusive of 9 subjects, more than 200 journals)

Providing 24-hour high-quality service

User-friendly online submission system

Fair and swift peer-review system

Efficient typesetting and proofreading procedure

Display of the result of downloads and visits, as well as the number of cited articles

Maximum dissemination of your research work

Submit your manuscript at: http://papersubmission.scirp.org/

Or contact me@scirp.org 